\title{
QUANTIFICATION OF HUMAN SEMINIFEROUS EPITHELIUM
}

\author{
II. HISTOLOGIGAL STUDIES IN EIGHT 47,XYY MEN
}
N. E. SKAKKEBÆK, MAJ HULTÉN, PETREA JACOBSEN AND MARGARETA MIKKELSEN

Chromosome Laboratory, Department of Obstetrics and Gynaecology, Rigshospitalet, University of Copenhagen, Denmark, Department of Clinical Genetics, Karolinska Sjukhuset, Stockholm, Sweden, Cytogenetic Laboratory, Institute for Mental Defectives for South East Futland, Brejning, and Chromosome Laboratory, Kennedy Institute, Glostrup, Denmark

\section{(Received 14th Fanuary 1972)}

Summary. Eight XYY men were investigated by a quantitative, histological analysis of the seminiferous epithelium. All but one had testes of normal size. Biopsy material from three men showed normal spermatogenesis, while severe impairment was found in a substantial number of the tubules in biopsies from five of the patients. The abnormalities included arrest of spermatogenesis at the primary spermatocyte level and tubules containing only Sertoli cells. These results correlate well with sperm counts which range from normal numbers to total aspermia.

Normal plasma levels of gonadotrophins were found in five of the six subjects examined; one of the six had a significantly increased level of FSH and another, an increased level of LH.

\section{INTRODUCTION}

The 47,XYY karyotype occurs in the general male neonatal population with an incidence of one to two/1000 (Sergovich, Valentine, Chen, Kinch \& Smout, 1969; Walzer, Breau \& Gerald, 1969; Ratcliffe, Stewart, Melville, Jacobs \& Keay, 1970; Lubs \& Ruddle, 1970). It has been suggested that the presence of an extra $\mathrm{Y}$ chromosome would lead to failure of spermatogenesis (Tettenborn, Schwinger \& Gropp, 1970; Hultén, 1970; Skakkebæk, 1970; Tettenborn, Gropp, Murken, Tinnefeld, Fuhrmann \& Schwinger, 1970), but no specific feature of testicular cytology or architecture has so far been associated with this karyotype.

In the present communication, we report on a quantitative, histological analysis of the seminiferous epithelium in eight males with a 47,XYY chromosome complement and summarize information from earlier investigations on the testicular histology of $47, \mathrm{XYY}$ men. Data on plasma levels of gonadotrophins are also presented. 


\section{MATERIALS AND METHODS}

Eight men with a 47,XYY karyotype were investigated. The subjects are listed in Table 1. One of the men (Subject 1) was found in an incidence study among members of 'King Size Club' in Stockholm, three men (Subjects 3, 4 and 7) were found in security hospitals in Sweden, three men (Subjects 2, 6 and 8) were found in incidence studies of mentally retarded offenders in Denmark and one (Subject 5) was investigated due to gigantism and acromegaly. None were discovered through infertility clinics. No evidence of chromosomal mosaicism was found in any of the cases as judged from analysis of forty-five or more cells from lymphnnyto cultures. All the men had normal sesnndary sex characteris tics, although Subject 5 had scanty pubic hair and beard and no axillary hair. The scrotum and penis were normally developed in all subjects. The testes, measured by an orchidometer, were of normal size, except in Subject 8 , who had small testes, each measuring $10 \mathrm{~cm}^{3}$ (lower normal limit, $15 \mathrm{~cm}^{3} ; \mathrm{N}$. E. Skakkebæk, unpublished).

Seminal fluid specimens were obtained repeatedly from four of the eight men and examined by the methods of Hammen (1944) and Eliasson (1971). Plasma FSH and plasma LH were measured by the radioimmunological method of Wide (1969).

Testicular tissue was removed surgically under local or general anaesthesia. The biopsies from Subjects 2, 3, 6 and 7 were fixed in Cleland's fixative, em bedded in paraplast and serially sectioned at $4 \mu$. The testicular biopsies from Subjects 1, 4, 5 and 8 were fixed in Stieve's solution and embedded in paraffin. In Subjects 1,4 and $8,6-\mu$ sections were used, while $8-\mu$ sections were studied in Subject 5. All material was stained with iron-haematoxylin according to the method of Rowley \& Heller (1966):

The tubule method of Rowley \& Heller (1971) was used for quantitative analysis of the seminiferous epithelium. This differential count is based upon the description of the epithelium by Clermont (1963) and Heller \& Clermont (1964). It was not possible to distinguish between different types of spermaton gonia in the biopsies fixed in Stieve's fluid and one of the biopsies fixed in Cleland's fixative. All counts were performed by the first author.

A differential count of germ cells and Sertoli cells was made on thirty randomly chosen tubule cross-sections in biopsies with only one category of tubules (Subjects 1 to 3). In Subjects 4 to 8 , two or more categories of tubules were present (e.g. tubules with spermatogenic arrest and tubules with complete spermatogenesis). In these cases, separate counts were made on thirty tubules

\section{EXPLANATION OF PLATE}

Fig. 1. Normal spermatogenesis in an XYY male (Subject 8). Cross-sections marked with arrows were those used for the quantitative analysis. A normal number of Leydig cells $(\mathrm{L})$ are apparently present, 150 .

Fig. 2. High-power magnification showing normal spermatogenesis (Subject 2). Sperา matogonia (Sg), spermatocytes (Set), meiotic division (M), early spermatids (Sa) and late spermatids' (Sd). $\quad 750$.

Fig. 3. Section of testicular biopsy from XYY male (Subject 7) with different categories of tubules with all types of germ cells $(\mathrm{N})$, with complete arrest at spermatocyte level (SA), and with Sertoli cells only (S), 


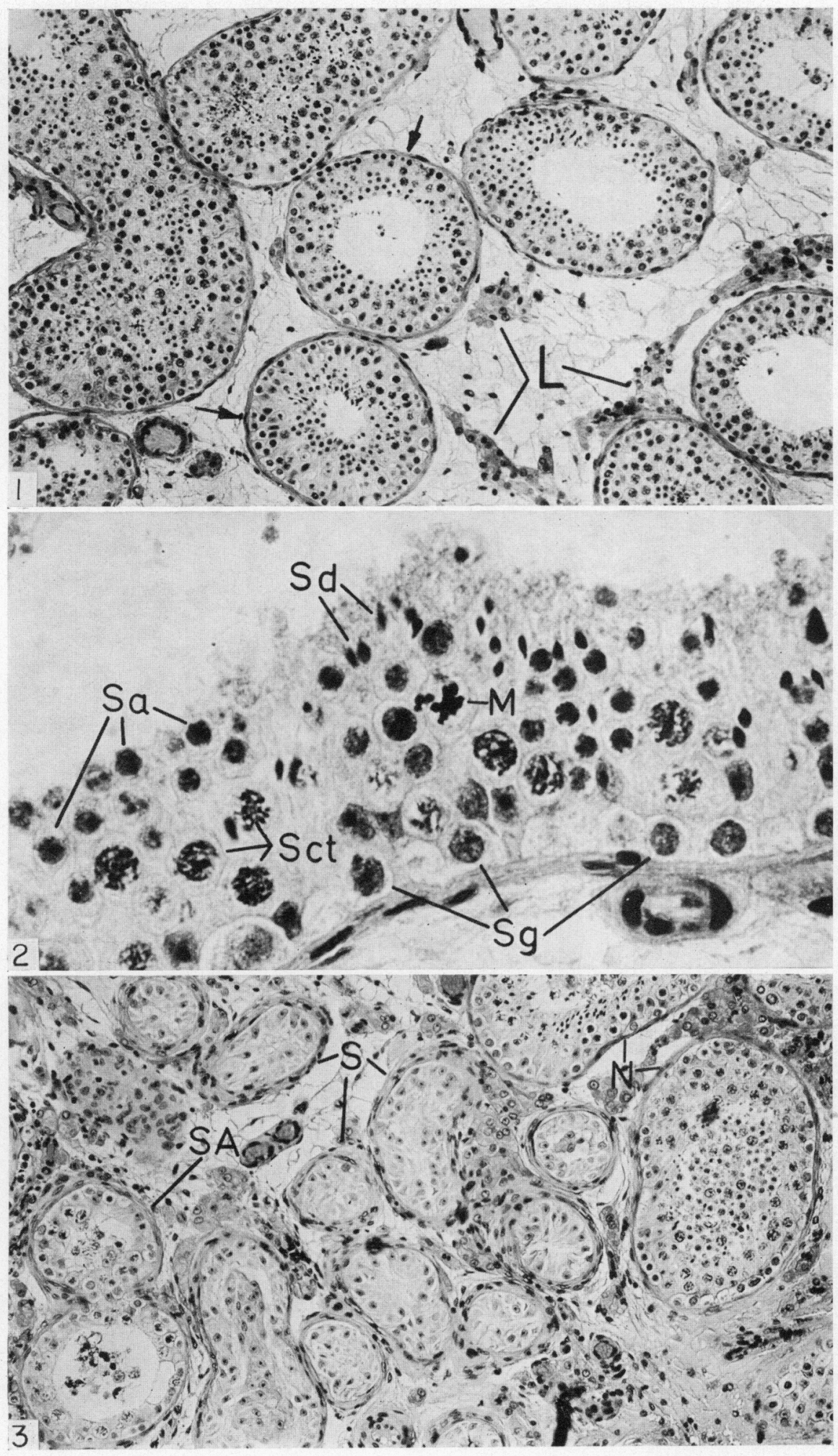




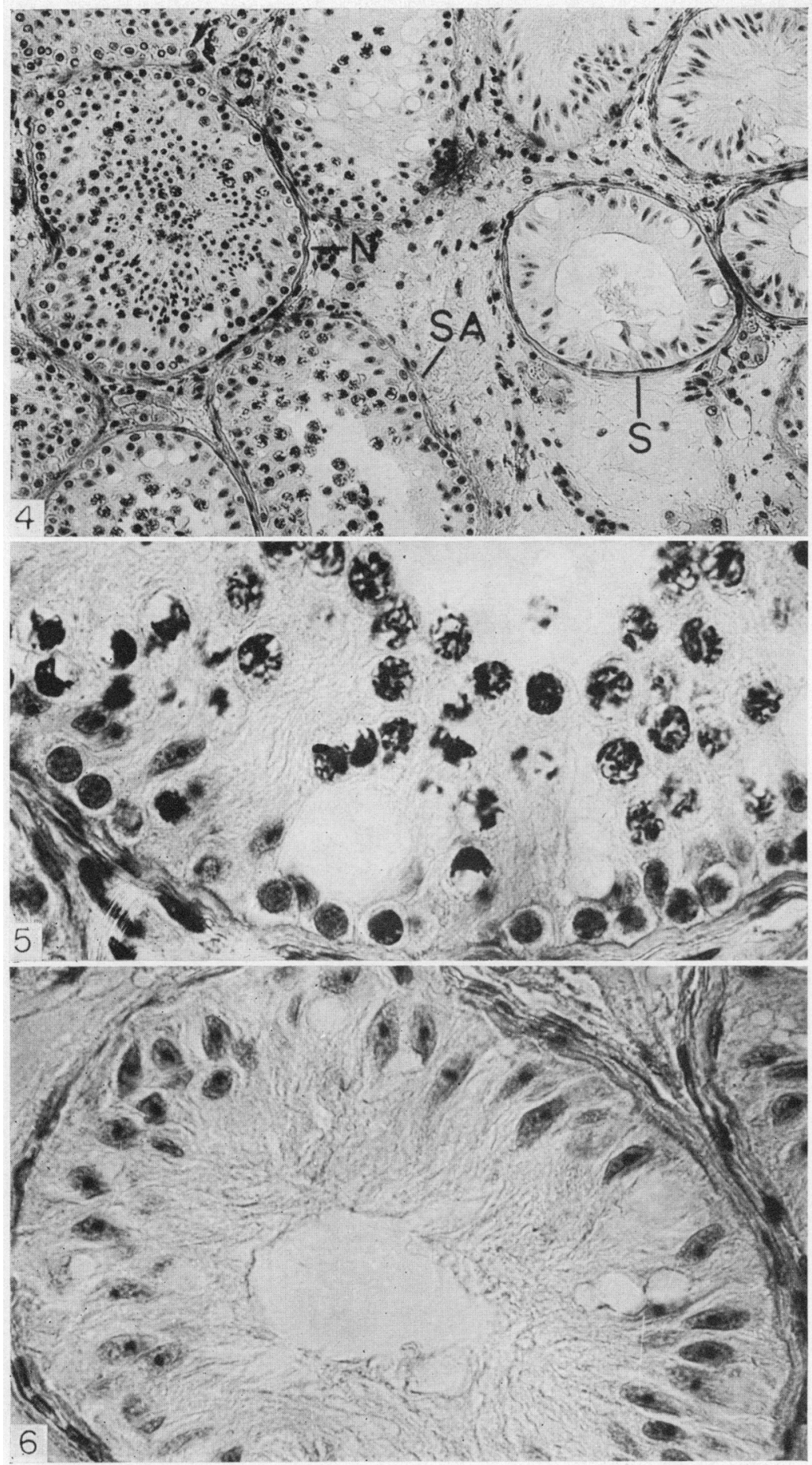

(Facing p. 393) 
from each category. Tubules containing only Sertoli cells were excluded from the counts. In some cases it was impossible to find thirty adequate tubules. The total number of counted germ cells of each of the different types was divided by the total number of Sertoli cells found in the same cross-sections of tubules. The resultant values are referred to as the Sertoli cell ratio (SCR).

In biopsies with a heterogenous picture, an estimate of the distribution of tubules of each category, e.g. tubules with spermatogenic arrest and 'Sertolicell-only' tubules, was determined by classification of all tubules in one randomly chosen section of a biopsy, and the estimates were expressed as a percentage of all tubules in this section. The findings were compared with similar studies of eighteen bilateral and three unilateral biopsies from a group of twenty-one fertile men with normal chromosome complements. In all biopsies from the controls, thirty tubules were examined (Skakkebæk \& Heller, 1973).

\section{RESULTS}

An apparently normal picture of testicular histology with one category of tubules was found in Subjects 1, 2 and 3 (Pl. 1, Figs 1 and 2). The SGR for these subjects fell within the range of the group of fertile 46,XY men (Tables 1 and 2, Text-fig. 1).

A heterogeneous picture was seen in Subjects 4, 5, 6, 7 and 8 (Pl. 1, Fig. 3 and Pl. 2, Figs 4, 5 and 6 ). Subject 4 had some tubules with apparently normal spermatogenesis $(13 \%)$ and others with a pronounced arrest at the primary spermatocyte level $(87 \%)$ (Table 2). No attempt was made to assess the cell content of tubules with apparently normal spermatogenesis because the biopsy was too small for a statistical evaluation of the differential count. The biopsy from Subject 5 contained two categories of tubules: one with almost total arrest $(78 \%)$ and the other with only Sertoli cells $(22 \%)$. A differential count of cells in tubules with spermatogenic arrest showed a somewhat lower SCR of spermatogonia and spermatocytes than the control group (Table 2). In Subject 6, three types of tubules were found, some with quantitatively normal spermatogenesis $(63 \%)$, some with total arrest at the spermatocyte level $(22 \%)$ and some containing only Sertoli cells and a reduced number of spermatogonia (15\%) (Table 2, Text-fig. 2). The biopsy in Subject 8 contained obliterated tubules $(17 \%)$ as well as tubules with apparently normal spermatogenesis (Table 2). However, the diameter of the latter tubules was increased (average tubular diameter $250 \mu \mathrm{m}$. The normal range for this laboratory is $197 \pm 30 \mu \mathrm{m})$. Subject

\section{EXPLANATION OF PLATE 2}

Fig. 4. Testicular biopsy from XYY male with the same categories of tubules as illustrated in Pl. 1, Fig. 3. Note that the tubular diameter of the 'Sertoli-cell-only' tubules (S) is only slightly decreased. $\times 175$. (The case was previously reported by Skakkebæk et al., 1970.)

Frg. 5. Same as Fig. 4. High-power magnification of a tubule with arrest at the pachytene level. Note the absence in obvious changes of the tubular membranes and many degenerated spermatocytes. $\times 750$.

Fig. 6. Same as Fig. 4. High power magnification of a tubule containing only Sertoli cells. Note absence of changes in tubular membranes and apparently normal morphology of the Sertoli cells. $\times 750$. 


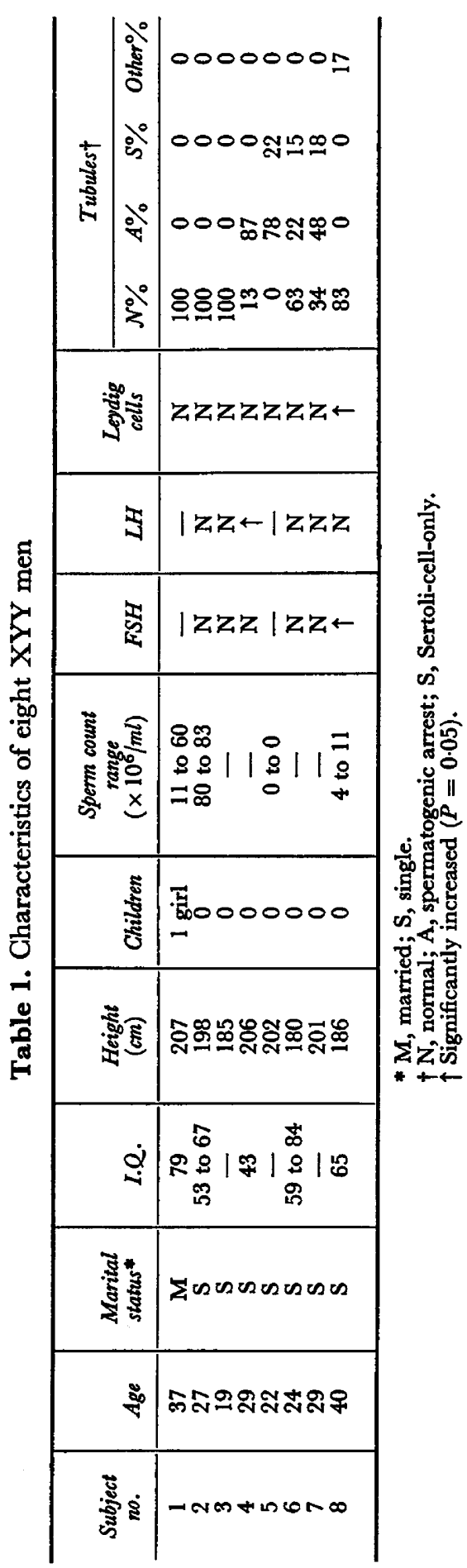




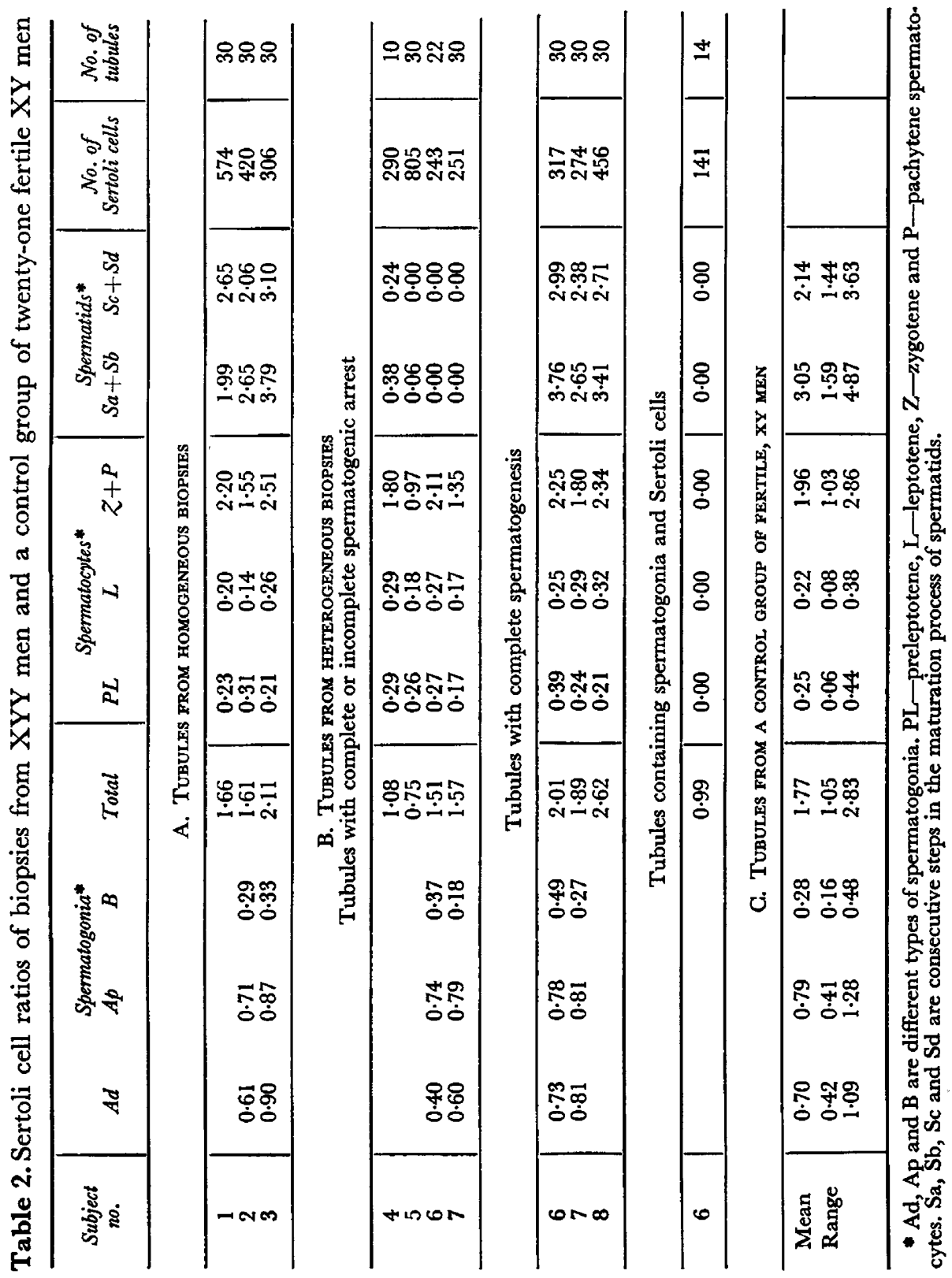


7 showed the most heterogeneous picture. Thirty-four per cent of the tubules had apparently normal spermatogenesis, while $48 \%$ showed a distinct arrest at the pachytene level, and $18 \%$ contained only Sertoli cells (Table 2, Pl. 1, Fig. 3).

Subject 8 appeared to have increased numbers of Leydig cells. All other biopsies appeared to have normal numbers of Leydig cells. Actual counts were not made.

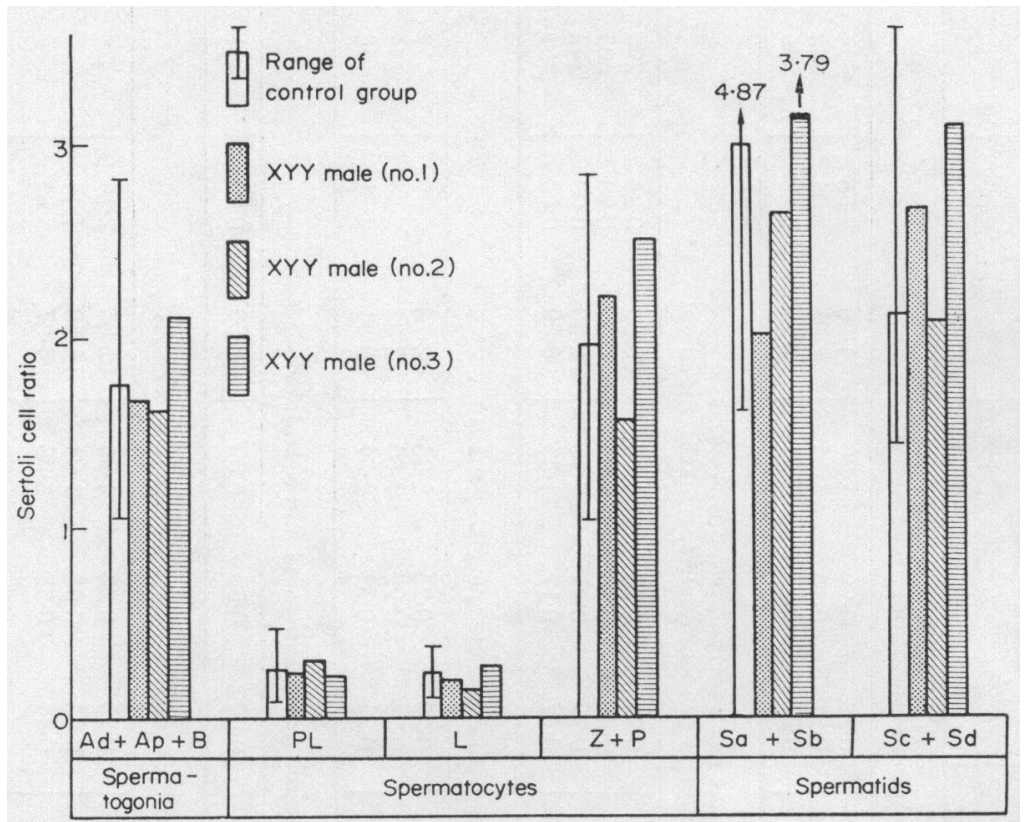

Text-FIG. 1. Sertoli cell ratios of different groups of germ cells in Subjects 1, 2 and 3 compared with values obtained from a study of fertile 46,XY men (Skakkebxk \& Heller, 1973). Note that results from the investigation of the XYY males fall within the normal range. Ad, Ap and $B$ are different types of spermatogonia. PL_preleptotene, $\mathrm{L}$-leptotene, $\mathrm{Z}$-zygotene and $\mathrm{P}$-pachytene spermatocytes. $\mathrm{Sa}, \mathrm{Sb}, \mathrm{Sc}$ and $\mathrm{Sd}$ are consecutive steps in the maturation process of spermatids.

Semen analyses for Subject 1 showed 30 to $45 \%$ motile cells and 50 to $60 \%$ morphologically normal cells in five specimens. Oligospermia was found in four of the samples $\left(11\right.$ to $18 \times 10^{6} / \mathrm{ml}$ ), and one sperm count was normal (60 $\times 10^{6} / \mathrm{ml}$ ). Two specimens from Subject 2 revealed normal sperm counts $(80$ and $83 \times 10^{6} / \mathrm{ml}$ ), $40 \%$ motile spermatozoa with rather good motility and $59 \%$ morphologically normal cells. Two specimens from Subject 5 revealed aspermia ( 7 and 9 spermatozoa in the sediment after centrifugation). The spermiogram for Subject 8 showed the following means for three specimens: $8.2 \times 10^{6} / \mathrm{ml}$, $43 \%$ motile cells and $30 \%$ abnormal forms.

Plasma FSH was significantly elevated in one man (Subject 8 ) with a value of $3.7 \mathrm{ng} / \mathrm{ml}$ (normal range 0.5 to $3.4 \mathrm{ng} / \mathrm{ml}$ (L. Wide, C. Gemzell, S. J. Nillius and $\mathrm{P}$. Roos, personal communication)). In the other subjects (2, 3, 4, 6 and 7), plasma FSH values ranged from 0.5 to $1.5 \mathrm{ng} / \mathrm{ml}$. Plasma $\mathrm{LH}$ was significantly elevated in one subject (Subject 4) with a value of $3.6 \mathrm{ng} / \mathrm{ml}$ 
(normal range 0.7 to $3.0 \mathrm{ng} / \mathrm{ml}$ (L. Wide, C. Gemzell, S. J. Nillius and P. Roos, personal communication)). In the remainder (Subjects 2, 3, 6, 7 and 8), plasma LH values ranged between 0.8 and $2.6 \mathrm{ng} / \mathrm{ml}$.

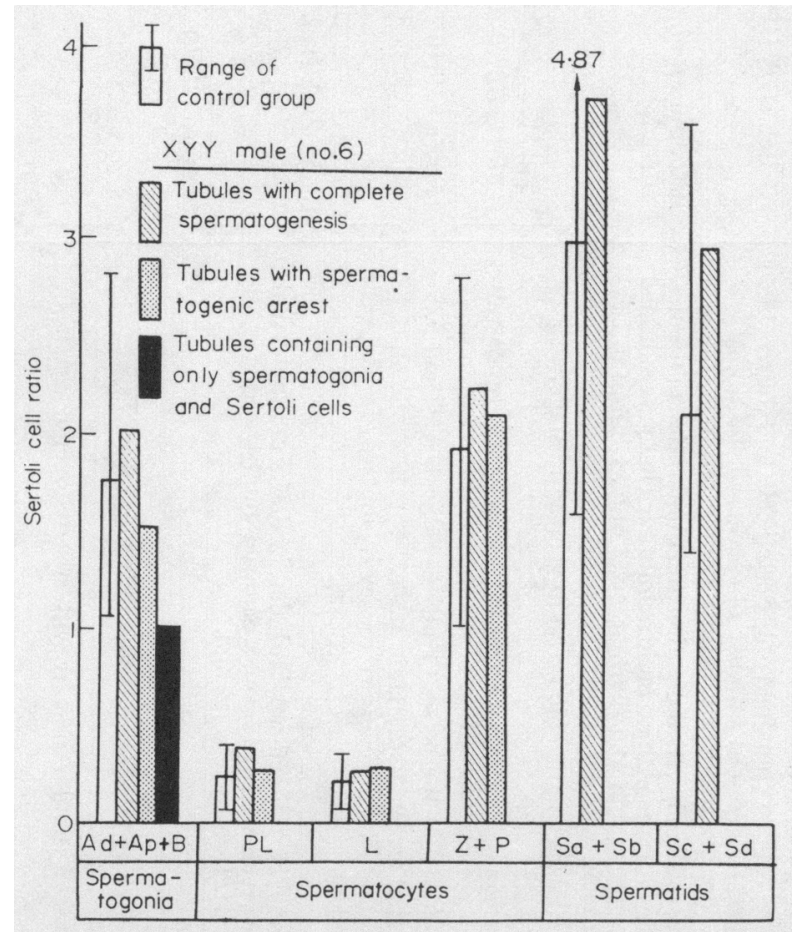

Text-Fig. 2. Sertoli cell ratios for Subject 6 . Results from quantitative analysis of the different categories of tubules compared with values obtained from a study of fertile 46, XY men (Skakkebak \& Heller, 1973). Ad, Ap and B are different types of spermatogonia. $\mathrm{PL}$-preleptotene, L-leptotene, $\mathrm{Z}$-zygotene and $\mathrm{P}$-pachytene spermatocytes. $\mathrm{Sa}, \mathrm{Sb}, \mathrm{Sc}$ and $\mathrm{Sd}$ are consecutive steps in the maturation process of spermatids.

\section{DISGUSSION}

The present investigation has shown a wide variation in the histological picture of the seminiferous epithelium within and between eight 47,XYY men. An apparently normal seminiferous epithelium was found in three of the cases, while the other five showed varying degrees of impairment of spermatogenesis. The most common pathological feature was an arrest at the spermatocyte level, but tubules containing only Sertoli cells were also found in several cases. These two types of tubules were sometimes found together or in combination with tubules containing all types of germ cells.

The same weight was not given to counts of ten, fourteen and twenty-two tubules (Table 2) as to counts of thirty tubules when evaluating the impairment of spermatogenesis. However, the counts for the smaller numbers of tubules deviated so much from the control values that no reasonable doubt could be given to the deficiencies of these tubule categories. 


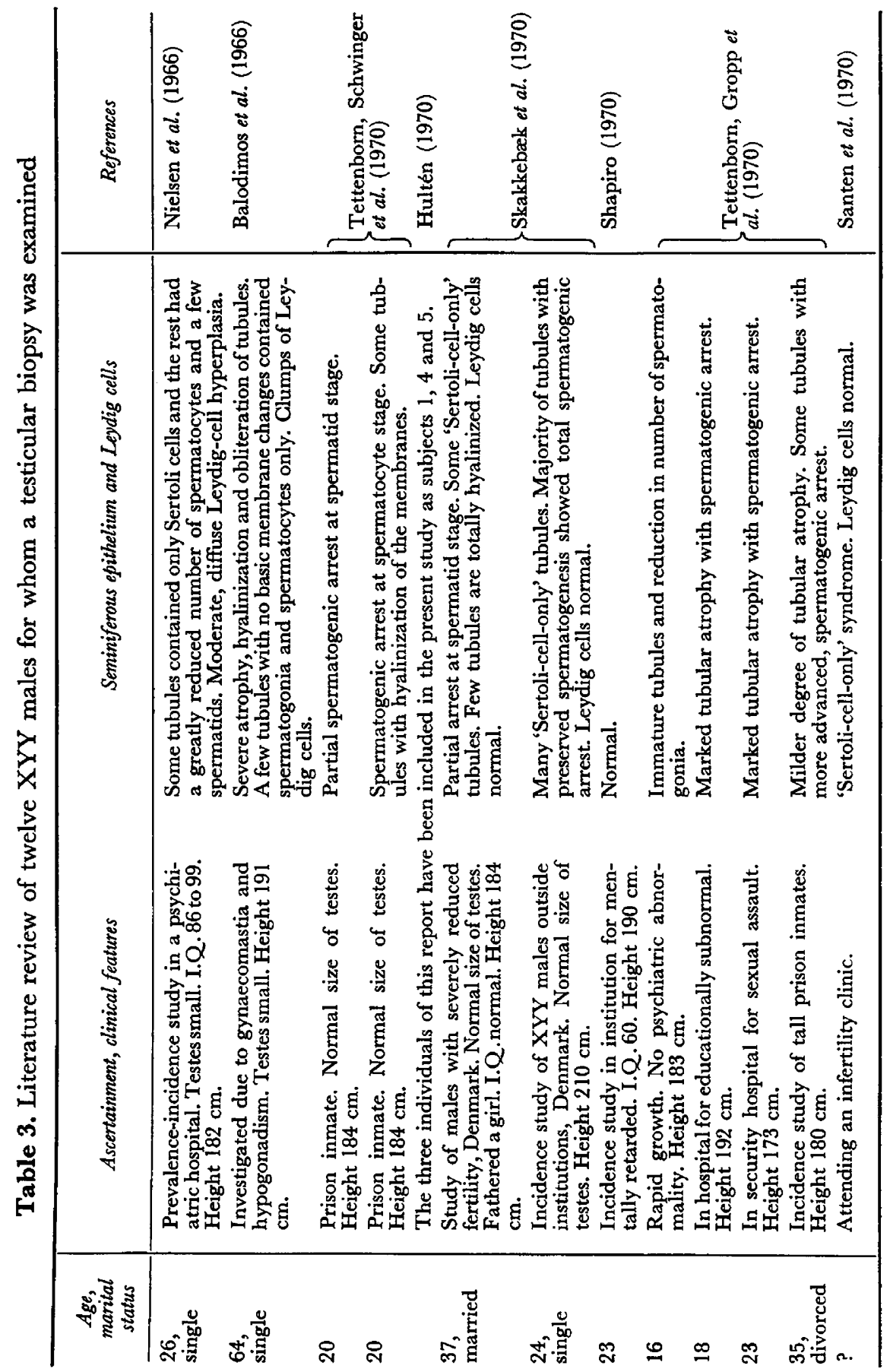


Although we believe that XYY males have an increased risk of testicular failure, the changes in the seminiferous epithelium do not have uniform characteristics. The same heterogeneous picture may be seen in patients with undescended testes (Johnsen, 1970), in oligospermic males with a normal 46,XY karyotype (Skakkebæk, Hammen, Philip \& Rebbe, 1972) as well as in men with various numerical and structural chromosomal aberrations (Skakkebæk, Hultén \& Philip, 1972).

Eleven of the twelve XYY males in previous reports on spermatogenesis were also said to have a wide range of various abnormalities of the seminiferous epithelium (Table 3). The frequency of such abnormalities in the general population is not known, although there is indirect evidence that it is much lower than among XYY men. Analysis of semen from a group of 100 apparently normal, young, unmarried men revealed aspermia or oligospermia in $22 \%$ (MacLeod \& Heim, 1945) and about 5\% of testes from men who died from accidents or suicide were found to be of the 'hypoplastic' type (Olesen, 1948). The finding of severe abnormalities in thirteen out of seventeen XYY men $(76 \%)$, not discovered because of suspicion of a testicular disorder (Tables 1 and 3), strongly suggests that the risk of XYY men having testicular disorders is increased.

The majority of the XYY men examined by others (Table 3 ) and by us were found in institutions. A significant number of randomly chosen XYY males living outside institutions should be examined to reveal whether an increased risk of testicular failure is also associated with XYY males in the general population.

Meiotic studies on XYY men have shown an apparent absence of the second Y chromosome in some of the germ cells (Thompson, Melnyk \& Hecht, 1967; Melnyk, Thompson, Rucci, Vanasek \& Hayes, 1969; Tettenborn, Schwinger \& Gropp, 1970; Hultén, 1970; Evans, Ford, Chaganti, Blank \& Hunter, 1970; Hultén \& Pearson, 1971; Tettenborn, Gropp, Murken, Tinnefeld, Fuhrmann \& Schwinger, 1970). An XYY male was studied by the recently introduced quinacrine fluorescence technique, and a higher proportion of germ cells with two $\mathrm{Y}$ chromosomes was identified than by conventional staining techniques (Hultén, 1970; Hultén \& Pearson, 1971). It remains to be seen if any relationship exists between the chromosomal constitution of the germ cells and the architecture of the germinal epithelium.

It should be noted that the finding of normal size testes and normal secondary sex characteristics does not exclude substantial testicular disorders. Only a few XYY males appear to have testes of subnormal size and secondary sex characteristics have been reported normal in almost all cases (Tables 1 and 3). This apparent paradox may be explained by the finding of tubules with disturbed spermatogenesis but with normal or only slightly reduced, or even increased, tubular diameter.

The number of Leydig cells was apparently normal in seven of the eight cases. None of the cases showed Leydig cell nodules as seen in Klinefelter's syndrome. However, minor changes in size and morphology cannot be excluded in the absence of quantitative objective measurements (Ahmad, Lennox \& Mack, 1969; Heller, Lalli, Pearson \& Leach, 1971). A detailed analysis of the 
frequency and morphology of the Leydig cells would be of interest in the light of the controversial results on pituitary hormones in XYY men. An increased excretion of urinary LH and a rise in serum LH has been reported by some investigators (Papanicolaou, Kirkham \& Loraine, 1968; Parker, 1969) but not confirmed by others (Hudson, Burger, Wiener, Sutherland \& Bartholomew, 1969; Santen, de Kretser, Paulsen \& Verhees, 1970). Our results are in line with the two latter reports. Plasma LH and plasma FSH were examined in six of the men and only one had a significantly increased level of plasma LH and another a significantly increased plasma FSH value.

\section{ACKNOWLEDGMENTS}

We are indebted to Dr L. Wide for performing radioimmunoassays of $\mathrm{LH}$ and FSH, Dr R. Hammen and Dr R. Eliasson for semen analysis, Dr S. G. Johnsen for one of the biopsies, Mrs Annelise Persson for technical assistance and to senior investigators, Miss Mavis Rowley and Dr Howard Morse, for their help and criticism of the manuscript.

This work was supported by grants from the Danish Medical Research Council, the Danish National Board of Social Welfare, Department of Mental Retardation and the Swedish Medical Research Council.

\section{REFERENCES}

Ahmad, K. N., Lennox, B. \& Mack, W. S. (1969) Estimation of the volume of Leydig cells in man. Lancet, ii, 461.

Balodimos, M. C., Lisco, H., Irwin, I., Merrili, W. \& Dingman, J. F. (1966) XYY karyotype in a case of familial hypogonadism. 7. clin. Endocr. Metab. 26, 443.

Clermont, Y. (1963) The cycle of the seminiferous epithelium in man. Am. F. Anat. 112, 35.

Eliasson, R. (1971) Standards for investigation of human semen. Andrologie, 3, 49.

Evans, E. P., Ford, G. E., Ghaganti, R. S. K., Blank, C. E. \& Hunter, H. (1970) XY spermatocytes in an XYY male. Lancet, $\mathbf{i}, 719$.

Hammen, R. (1944) Impaired fertility in man with special reference to the male. Munksgaard. Copenhagen.

Heller, G. G. \& Glermont, Y. (1964) Kinetics of the germinal epithelium in man. Recent. Prog. Horm. Res. 20, 545.

Heller, G. G., Lalli, M. F., Pearson, J. E. \& Leach, D. R. (1971) A method for the quantification of Leydig cells in man. 7. Reprod. Fert. 25, 177.

Hudson, B., Burger, H., Wiener, S., Sutherland, G. \& Bartholomew, A. A. (1969) Plasma testosterone and luteinizing hormone in XYY men. Lancet, ii, 699.

Hultén, M. (1970) Meiosis in XYY men. Lancet, i, 717.

Hultén, M. \& Pearson, P. L. (1971) Fluorescent evidence for spermatocytes with two Y chromosomes in an XYY male. Ann. hum. Genet. 34, 273.

Johnsen, S. G. (1970) Testicular biopsy score count. Hormones, $1,1$.

LuBs, H. A. \& RuddLe, F. H. (1970) Chromosome abnormalities in the human population. Science, N.Y. $169,495$.

MacLeod, J. \& Heim, L. M. (1945) Characteristics and variation in semen specimens in 100 normal young men. 7 . Urol. 54, 474.

Melnyk, J., Thompson, H., Rucci, A., Vanasex, F. \& Hayes, S. (1969) Failure of transmission of the extra chromosome in subjects with 47,XYY karyotype. Lancet, ii, 797.

Nielsen, J., Ghristensen, A. L., Johnsen, S. G. \& Frøland, A. (1966) Psychopathology and testis histology in a patient with the XYY syndrome. Acta med. scand. 180, 747.

Olesen, H. (1948) Morphological studies on semen and testes. Munksgaard, Copenhagen.

Papanicolaou, A. D., Kirkham, K. E. \& Loraine, J. A. (1968) Abnormalities in urinary gonadotrophin excretion in men with a 47,XYY sex chromosome constitution. Lancet, ii, 608.

Parker, C. E. (1969) Luteinizing hormone in XYY men. Lancet, i, 1101.

Ratcliffe, S. G., Stewart, A. L., Melville, M. M., Jacobs, P. A. \& Keay, A. J. (1970) Chromosome studies on 3500 new-born male infants. Lancet, $\mathbf{i}, 121$. 
Rowley, M. J. \& Heller, C. G. (1966) The testicular biopsy: surgical procedure, fixation and staining technics. Fert. Steril. 17, 177.

Rowley, M. J. \& HeLler, C. G. (1971) Quantification of the cells of the seminiferous epithelium of the human testis employing the Sertoli cell as a constant. Z. Zellforsch. mikrosk. Anat. 115, 461.

Santen, R. J., De Kretser, D. M., Paulsen, C. A. \& Verhees, J. (1970) Gonadotrophins and testosterone in the XYY syndrome. Lancet, ii, 371.

Sergovich, F., Valentine, G. H., Chen, A. T. L., Kinch, R. A. H. \& Smout, M. S. (1969) Chromosome aberrations in 2159 consecutive newborn babies. New Engl. F. Med. 280, 851.

ShapIRo, L. R. (1970) Hormones and the XYY male. Lancet, i, 1347.

SkakkeBak, N. E. (1970) Hormones and the XYY male. Lancet, i, 949.

Skakkebax, N. E., Hammen, R., Philip, J. \& Rebbe, H. (1972) Quantification of human seminiferous epithelium. III. Histological studies in 44 infertile men with normal chromosome complements. Acta path. microbiol. scand. (in press.)

Skakkeberk, N. E. \& Heller, C. G. (1973) Quantification of human seminiferous epithelium. I. Histological studies in twenty-one fertile men with normal chromosome complements. $\mathcal{f}$. Reprod. Fert. 32, 379.

Skakkebek, N. E., Hultén, M. \& Philip, J. (1972) Quantification of human seminiferous epithelium. IV. Histological studies in 17 men with numerical and structural aberrations. Acta path. microbiol. scand. (in press).

Skakkebak, N. E., Philip, J., Mikxelsen, M., Hammen, R., Nielsen, J., Perbøll, O. \& Yde, H. (1970) Studies on spermatogenesis, meiotic chromosomes and sperm morphology in two males with a 47, XYY chromosome complement. Fert. Steril. 21, 645.

Tettenborn, U., Gropp, A., Murken, J. D., Tinnefeld, W., Fuhrmann, W. \& Schwinger, E. (1970) Meiosis and testicular histology in XYY males. Lancet, ii, 267.

Tetrenborn, U., Schwinger, E. \& GRoPP, A. (1970) Testicular function in men with XYY chromosomes. Dt. med. Wschr. 95, 158.

Thompson, H., Melnyk, J. \& Hecht, F. (1967) Reproduction and meiosis in XYY. Lancet, ii, 831.

Walzer, S., Breau, G. \& Gerald, P. S. (1969) A chromosome survey of 2400 normal newborn infants. F. Pediat. 74, 438.

WIDE, L. (1969) Radioimmunoassays employing immunosorbents. Acta endocr., Copenh. 63, Suppl. 142, 207. 